\title{
Falsely diagnosed thyrotoxicosis caused by anti-streptavidin antibodies and pre-wash procedures
}

Takuya Ishikawa, Hiroyuki Sakai, Tokutaro Itaya, Suwanai Hirotsugu, Jumpei Shikuma, Takashi Miwa, Ryo Suzuki and Masato Odawara

\begin{abstract}
Background: Anti-streptavidin antibodies are causal determinants of analytical interference during Thyroid function tests, and numerous reports have detailed such interference, with anti-streptavidin antibodies attracting attention.

Case presentation: We conducted a straightforward investigation of interference due to anti-streptavidin antibodies, with a case of a 60-year-old Japanese man who consulted our department for inconsistencies between his clinical course and Thyroid function tests. Experiments were conducted using Cobas8000 e602, which employs assay procedures with pre-wash to evaluate FT4 and FT3 levels.

Conclusions: To our knowledge, this is the first published report to clearly investigate such interferences using a combination of polyethylene glycol precipitation, heterophilic blocking tube precipitation, streptavidin-coated magnetic particle precipitation, and different instruments with or without pre-wash. Clinicians should consider that interferences caused by anti-streptavidin antibodies could lead to a misdiagnosis of thyrotoxicosis. Moreover, discussions between laboratory specialists, clinicians, and manufacturers are required to identify interferences and avoid unnecessary examinations and inappropriate treatment.
\end{abstract}

Keywords: Immunoassay interference, Thyroid function tests, Anti-streptavidin antibody, Pre-wash

\section{Background}

Typical thyroid function tests (TFTs) usually evaluate thyrotropin (TSH), free thyroxine (FT4), and free triiodothyronine (FT3) levels [1]. Anti-streptavidin antibodies are causal determinants of analytical interference during TFTs [2,3], and numerous reports have detailed such interference, with anti-streptavidin antibodies attracting attention [1, 4-7]. We conducted a straightforward investigation of interference due to antistreptavidin antibodies during TFTs. Experiments were conducted using Cobas8000 e602, which employs assay procedures with pre-wash to evaluate FT4 and FT3

\footnotetext{
* Correspondence: hirosaka@tokyo-med.ac.jp

Department of Diabetes, Metabolism and Endocrinology, Tokyo Medical University, 6-7-1 Nishishinjuku Shinjuku-ku, Tokyo 160-0023, Japan
}

levels. All the measurements for FT4 were examined using FT4 II reagent while measurements of FT3 were examined with FT3 III reagent.

\section{Case presentation}

We report a case of a 60-year-old Japanese man who consulted our department for inconsistencies between his clinical course and TFTs. He had undergone right subtotal thyroidectomy for papillary thyroid carcinoma when he was 57 years old. After surgery, levothyroxine replacement at $100 \mu \mathrm{g} /$ day was used to control his thyroid hormone levels. For over 2 years, TFTs revealed normal TSH, FT4, and FT3 levels. However, 28 months after thyroidectomy, abrupt changes in TSH $(0.05 \mu \mathrm{IU} /$ $\mathrm{mL})$, FT4 $(3.24 \mathrm{ng} / \mathrm{dL})$, and FT3 $(7.00 \mathrm{pg} / \mathrm{mL})$ were

(c) The Author(s). 2021 Open Access This article is licensed under a Creative Commons Attribution 4.0 International License, which permits use, sharing, adaptation, distribution and reproduction in any medium or format, as long as you give appropriate credit to the original author(s) and the source, provide a link to the Creative Commons licence, and indicate if changes were made. The images or other third party material in this article are included in the article's Creative Commons licence, unless indicated otherwise in a credit line to the material. If material is not included in the article's Creative Commons licence and your intended use is not permitted by statutory regulation or exceeds the permitted use, you will need to obtain permission directly from the copyright holder. To view a copy of this licence, visit http://creativecommons.org/licenses/by/4.0/ The Creative Commons Public Domain Dedication waiver (http://creativecommons.org/publicdomain/zero/1.0/) applies to the data made available in this article, unless otherwise stated in a credit line to the data. 
observed (each reference range is shown in Tables 1 and 2). Anti-TSH receptor antibodies (TRAb) were slightly positive $(2.1 \mathrm{IU} / \mathrm{L}$; reference range: <2.0 IU/L). Subsequently, the surgeon established a diagnosis of thyrotoxicosis and discontinued levothyroxine. Since the TFT results did not improve, the surgeon started potassium iodide treatment. Nevertheless, the TFTs still revealed a pattern of syndrome of inappropriate secretion of TSH (SITSH) (Table 1, before polyethylene glycol (PEG) precipitation (Tx)), which prompted consultation with our department. Upon consultation, the patient presented with no typical symptoms of thyrotoxicosis. He did not take any biotin related supplments. Therefore, considering the possibility of a false SITSH, PEG Tx using the same sera was performed.

PEG Tx was performed following previously described procedures $[8,9]$. PEG Tx promoted high levels of TSH but low FT3 and FT4 recovery. Subsequently, Heterophilic Blocking Tube (HBT) (Scantibodies Laboratory, Santee, CA, USA) Tx was performed to remove heterophilic antibodies. HBT Tx results thereafter showed that the patient's sample recorded higher levels of TSH and lower FT3 and FT4 recovery compared to those of the control samples. Furthermore, two additional assays were subsequently performed: (1) the Elecsys assay using Cobas e411, which employs the same method as Cobas8000 e602 except for the pre-wash procedure, and (2) The two-step method, Architect assay, which utilizes a completely different method than the one-step Elecsys assay.
Evaluating the thyroid function using the Architect method resulted in a higher TSH level and lower FT4 and FT3 values compared with the Elecsys method. Since Cobas e411 is not performed with a pre-wash, Cobas e411 was used to compare the possible effects of pre-wash in the thyroid function evaluation. As such, both FT4 and FT3 values were lower with Cobas e411 than with Cobas8000 e602. Nonetheless, the TSH values measured using Elecsys, which does not include prewash, produced similar results (shown in Table 2). We further examined whether anti-streptavidin antibodies interfere with TFTs by adding streptavidin-coated magnetic particles (SA-MP) (shown in Table 1). The experiment showed higher TSH and lower FT3 and FT4 recovery in the patient's sample. We consequently concluded that interference was caused by the streptavidin antibodies.

One year after consultation, false values of the TFTs were gradually improving, so the patient resumed the original with levothyroxine treatment at $100 \mu \mathrm{g} /$ day. (TSH: $1.60 \mu \mathrm{IU} / \mathrm{mL}$, FT3: $3.05 \mathrm{pg} / \mathrm{mL}$, FT4: $1.39 \mathrm{ng} / \mathrm{dL}$ ).

\section{Discussion and conclusions}

Of note, Lam et al. have identified two cases of IgM anti-streptavidin antibodies causing analytic interference during TFT [4], and Verougstraete et al. have implicated IgM (rather than IgG) in such interference [10]. The relatively brief period ( 1 year) during which our patient was plagued by false values is further evidence that antistreptavidin antibodies are likely IgM type. Indeed, several case reports have indicated falsely increased and

Table 1 Detection and characterization of interference using polyethylene glycol, heterophilic blocking tube, and streptavidincoated magnetic particle SA-MP treatment

TSH, $\mu$ IU/mL (RR: 0.50-5.00)

Patient

$\begin{array}{ll}\text { Before PEG Tx } & 4.67 \\ \text { After PEG Tx (actual measured value) } & 4.77 \\ \text { After PEG Tx (calculated value) } & 9.54 \\ & \text { TSH } \\ \text { Recovery (\%) } & 204 \text { (RR: 30-80) } \\ & \text { TSH, } \mu \text { lU/mL (RR: 0.50-5.00) } \\ \text { Patient } & 4.36 \\ \text { Before HBT Tx or SA-MP Tx } & 6.49 \\ \text { After HBT Tx } & 9.81 \\ \text { After SA-MP Tx } & \\ \text { Control } & 3.65 \\ \text { Before HBT Tx and SA-MP Tx } & 3.69 \\ \text { After HBT Tx } & 3.64 \\ \text { After SA-MP Tx } & \end{array}$

FT4, ng/dL (RR: 0.90-1.70) FT3, pg/mL (RR: 2.3-4.0)

2.66
0.87
$=$
FT4

33 (RR: 60-90)

FT4, ng/dL (RR: 0.90-1.70)
5.88

2.11

$=$

FT3

36 (RR: 60-90)

FT3, pg/mL (RR: 2.3-4.0)

PEG Tx resulted in a high TSH level but low FT4 and FT3 recovery. HBT Tx or SA-MP Tx resulted in a higher TSH but lower FT4 and FT3 values. However, HBT Tx or SA-MP Tx showed almost the same results in the control sample 
Table 2 Thyroid function test parameters as measured by different immunoassays (Elecsys and Architect)

\begin{tabular}{|c|c|c|c|}
\hline & \multicolumn{2}{|l|}{ Elecsys } & \multirow[t]{2}{*}{ Architect } \\
\hline & Cobas8000 e602 (with pre-wash) & Cobas e411(without pre-wash) & \\
\hline \multicolumn{4}{|l|}{ Patient } \\
\hline $\mathrm{TSH}, \mu \mathrm{IU} / \mathrm{mL}$ & 4.36 (RR: $0.50-5.00)$ & 4.77 (RR: 0.50-5.00) & 8.57 (RR: 0.35-4.94) \\
\hline $\mathrm{FT} 4, \mathrm{ng} / \mathrm{dL}$ & 2.15 (RR: 0.90-1.70) & 1.31 (RR: 0.90-1.70) & 0.86 (RR: 0.70-1.48) \\
\hline $\mathrm{FT} 3, \mathrm{pg} / \mathrm{mL}$ & 4.27 (RR: $2.3-4.0)$ & 3.66 (RR: $2.3-4.0)$ & 2.44 (RR: 1.71-3.71) \\
\hline
\end{tabular}

Cobas8000 e602, which is performed with pre-washing, resulted in almost the same level of TSH and with higher FT4 and FT3 values compared to Cobas e411, which is not performed with pre-wash. Architect provided the highest TSH level and lowest FT4 and FT3 values among the three instruments

decreased values for TFTs due to anti-streptavidin antibodies. However, to our knowledge, this is the first published report to clearly investigate such interferences using a combination of PEG Tx, HBT Tx, SA-MP Tx, and different instruments with or without pre-wash. Our experiment revealed that pre-wash probably increased measurement error during TFTs. Given that Cobas 8000 e602 performs $\mathrm{B} / \mathrm{F}$ separation by pre-wash before $\mathrm{B} / \mathrm{F}$ separation in the measuring cell, non-specific reactions due to anti-streptavidin antibodies increased more with Cobas8000 e602 than with Cobas e411. Altogether, the anti-streptavidin antibodies in the patient's serum interacted with streptavidin in the assay reagents, thus leading to a reduced luminescence signal and falsely increased FT4 and FT3 values with a competitive immunoassay. Additionally, more attention should be placed on the finding that TRAb values returned to the reference value within 1 year $(1.0 \mathrm{IU} / \mathrm{L})$. The Elecsys TRAb competitive assay similarly tends to produce falsely elevated values in the presence of antistreptavidin antibodies. We are unable to offer corroboration, because TRAb was not investigated in tandem with FT4 and FT3 on this occasion. Still, cases of thyrotoxicosis ascribed to anti-streptavidin antibodies have been linked to falsely high values of TRAb in past reports [1.4.7]. The clinical course of such current patient might be misdiagnosed of thyrotoxicosis due to Graves' disease, and the patient might have seemed to be cured within 1 year through unnecessary antithyroid drugs unless we had suspected interference due to antistreptavidin antibodies. Studies have shown that interference due to anti-streptavidin antibodies is not rare [10]. Clinicians should consider that interferences caused by IgM anti-streptavidin antibodies could lead to a misdiagnosis of thyrotoxicosis. With such uncertain cases, we recommend that PEG Tx be performed to determine the potential for interference. Recently, the Elecsys kit improved its reagent for FT4, which reduces interference by anti-streptavidin antibodies. However, reagents for TSH and FT3 have not been improved yet. Therefore, discussions between laboratory specialists, clinicians, and manufacturers are required to identify interferences and avoid unnecessary examinations and inappropriate treatment. In conclusion, through the combination of PEG Tx, HBT Tx, SA-MP Tx, and other measurement methods, we showed that anti-streptavidin antibodies caused interference during TFTs.

\section{Abbreviations}

TFTs: Typical thyroid function tests; TSH: Thyrotropin; FT4: Free thyroxine; FT3: Free triiodothyronine; TRAb: Anti-TSH receptor antibodies; SITS $\mathrm{H}$ : Syndrome of inappropriate secretion of TSH; PEG: Polyethylene glycol; Tx: Precipitation; HBT: Heterophilic Blocking Tube; RR: Reference range; SAMP: Streptavidin-coated magnetic particles

\section{Acknowledgments}

The authors wish to thank the Section of Biochemistry, Central Clinical Laboratory Division, Tokyo Medical University Hospital and acknowledge the English language assistance of enago.jp (https://www.enago.jp) and BioMed Proofreading LLC (http://www.BioMedProofreading.jp/).

\section{Employment or leader ship}

None declared.

\section{Honorarium}

None declared.

\section{Authors' contributions}

The authors thank the Department of Diabetes, Metabolism, and Endocrinology, Tokyo Medical University for their support in establishing this case report. All authors take responsibility for the entire content of this manuscript and agree to be accountable for the accuracy and integrity of the work and ensure that questions are appropriately investigated and resolved. All authors have approved of its submission.

\section{Funding}

None declared.

\section{Availability of data and materials}

The datasets used and/or analyzed during the present study are available from the corresponding author upon reasonable request.

\section{Declarations}

Ethics approval and consent to participate

Written informed consents of the case-patient were obtained in accordance with the declaration of Helsinki.

\section{Competing interests}

The authors have no competing interests to declare.

Received: 5 April 2021 Accepted: 2 July 2021

Published online: 10 July 2021

References

1. Peltier L, Massart C, Moineau MP, Delhostal A, Roudaut N. Anti-streptavidin interferences in Roche thyroid immunoassays: a case report. Clin Chem Lab Med. 2016;54(1):e11-4. https://doi.org/10.1515/cclm-2015-0350. 
2. Rulander NJ, Cardamone D, Senior M, Snyder PJ, Master SR. Interference from anti-streptavidin antibody. Arch Pathol Lab Med. 2013;137(8):1141-6. https://doi.org/10.5858/arpa.2012-0270-CR.

3. Elston MS, Sehgal S, Du Toit S, Yarndley T, Conaglen JV. Factitious Graves' disease due to biotin immunoassay interference-a case and review of the literature. J Clin Endocrinol Metab. 2016;101(9):3251-5. https://doi.org/10.121 0/jc.2016-1971.

4. Lam L, Bagg W, Smith G, Chiu WW, Middleditch MJ, Lim JC, et al. Apparent hyperthyroidism caused by biotin-like interference from IgM antistreptavidin antibodies. Thyroid. 2018;28(8):1063-7. https://doi.org/10.1089/ thy.2017.0673.

5. Favresse J, Lardinois B, Nassogne MC, Preumont V, Maiter D, Gruson D. Antistreptavidin antibodies mimicking heterophilic antibodies in thyroid function tests. Clin Chem Lab Med. 2018;56(7):e160-3. https://doi.org/10.151 5/cclm-2017-1027.

6. Ruth I, Mathieu E, Burniat A, Fage D, Cotton F, Wolff F. Interferences in free thyroxine concentration using the Roche analytical platform: improvement of the third generation? Clin Chem Lab Med. 2020;58(2):e36-9. https://doi. org/10.1515/cclm-2019-0525.

7. Wouters Y, Oosterbos J, Reynaert N, Penders J. Alarmed by misleading interference in free $\mathrm{T} 3$ and free T4 assays: a new case of anti-streptavidin antibodies. Clin Chem Lab Med. 2020;58(3):e69-71. https://doi.org/10.1515/ cclm-2019-0845.

8. Sakai H, Fukuda G, Suzuki N, Watanabe C, Odawara M. Falsely elevated thyroid-stimulating hormone (TSH) level due to macro-TSH. Endocr J. 2009; 56(3):435-40. https://doi.org/10.1507/endocri.K08E-361.

9. Bayart JL, Favresse J, Melnik E, Lardinois B, Fillee C, Maiter D, et al. Erroneous thyroid and steroid hormones profile due to anti-streptavidin antibodies. Clin Chem Lab Med. 2019;57(10):e255-8. https://doi.org/10.1515/cclm-201 8-1355.

10. Verougstraete N, Berth M, Vaneechoutte M, Delanghe J, Callewaert N. Interference of anti-streptavidin antibodies in immunoassays: a very rare phenomenon or a more common finding? Clin Chem Lab Med. 2020;58(10): 1673-80. https://doi.org/10.1515/cclm-2019-1064.

\section{Publisher's Note}

Springer Nature remains neutral with regard to jurisdictional claims in published maps and institutional affiliations.

Ready to submit your research? Choose BMC and benefit from:

- fast, convenient online submission

- thorough peer review by experienced researchers in your field

- rapid publication on acceptance

- support for research data, including large and complex data types

- gold Open Access which fosters wider collaboration and increased citations

- maximum visibility for your research: over $100 \mathrm{M}$ website views per year

At $\mathrm{BMC}$, research is always in progress.

Learn more biomedcentral.com/submissions 